\title{
PENGARUH KECEMASAN MATEMATIKATERHADAP HASIL BELAJAR MATEMATIKA DITINJAU DARI GAYA BELAJAR SISWA KELAS VIII SMP NEGERI 4 KENDARI
}

\author{
Nur Hajarus Afiatman ${ }^{1)}$, Hafiludin S. ${ }^{2)}$, Mustamin Anggo ${ }^{3)}$ \\ 1) Alumni Jurusan Pendidikan Matematika, ${ }^{2,3)}$ Dosen Jurusan Pendidikan Matematika \\ FKIP Universitas Halu Oleo. Email: nurhajarusafiatman01@gmail.com; \\ hafiludin79@yahoo.com; mustaminanggo@yahoo.com
}

\begin{abstract}
Abstrak
Penelitian ini bertujuan untuk mengetahui pengaruh kecemasan matematikaterhadap hasil belajar matematika ditinjau dari gaya belajar siswa kelas kelas VIII SMP Negeri 4 Kendari. Populasi dalam penelitian ini melibatkan seluruh siswa kelas VIII SMP Negeri 4 Kendari tahun pelajaran 2018/2019 yang terdistribusi dalam 11 kelas. Penentuan sampel dalam penelitian ini dilakukan dengan menggunakan teknik Propotional Random Sampling.Kemudian, dipilih sampel kelas sebanyak 165 siswa sebagai sampel. Pengumpulan data dilakukan dengan cara pengumpulan angket dan dokumentasi. Teknik analisis data menggunakan statistik deskriptif dan statistik inferensial. Berdasarkan hasil penelitian, diperoleh kesimpulan terdapat pengaruh yang signifikan antara kecemasan matematika terhadap hasil belajar matematika kelas VIII SMP Negeri 4 Kendari.
\end{abstract}

Kata Kunci: kecemasan matematika, gaya belajar, hasil belajar matematika

THE MATHEMATICAL ANXIETYINFLUENCE FOR MATHEMATICS LEARNING OUTCOMES IN THE LEARNING STYLE OF CLASS VIII SMP NEGERI 4 KENDARI

\begin{abstract}
This research aims to know the mathematical anxiety influence for mathematics learning outcomes in the learning style of Class VIII SMP Negeri 4 Kendari. The research used propotional random sampling technique by takingall of class VIII students SMP Negeri 4 Kendari 2018/2019 period who distributed in 11 classes. Thus dertemine the numbesr of sample are 165 students. collecting the data by questioner and document instruments. in analysis the data used descriptive statisctic and inferential statisctic technique. Based on the research result, the conclution obtained there is significance influence between mathematical anxienty to mathematic learning style of class VIII SMP Negeri 4 Kendari.
\end{abstract}

Keywords: mathematic anxiety, learning style, mathematic learning outcome 


\section{Pendahuluan}

Pendidikan mempunyai peran yang penting bagi peningkatan kualitas dan mutu sumber daya manusia. Suatu bangsa akan tertinggal dari bangsa lain apabila pendidikan rakyatnya rendah dan tidak berkualitas. Sebaliknya, suatu negara dan bangsa akan menjadi maju apabila rakyatnya memiliki pendidikan yang tinggi dan berkualitas. Tanpa sumber daya manusia yang berkualitas, suatu bangsa akan tertinggal dari bangsa lain dalam percaturan dan persaingan kehidupan global yang makin kompetitif. Kualitas sumber daya manusia salah satunya dapat diketahui berdasarkan kualitas pendidikan suatu bangsa. Maju dan mundurnya suatu bangsa juga dapat diketahui berdasarkan kualitas pendidikan.

Kualitas pendidikan di Indonesia masih dinilai rendah oleh pemerhati pendidikan di Indonesia. Survey "Trends in International Math and Science" oleh Global Institute pada tahun 2007, yang di kemukakan Kompasiana (2013), survey tersebut hanya 5\% siswa Indonesia yang mampu mengerjakan soal berkategori tinggi yang memerlukan penalaran sedangkan siswa Korea yang sanggup mengerjakannya mencapai $71 \%$. Programme for International Student Assessment (PISA) pada tahun 2009 menempatkan Indonesia di peringkat 10 besar terakhir dari 65 negara peserta PISA. Kriteria yang dinilai berupa kemampuan kognitif dan keahlian siswa membaca, matematika, dan sains. Penguasaan siswa indonesia hanya sampai level 3 sementara negara lain sampai level 4,5 dan 6 . Kedua survey ini menunjukkan kualitas pendidikan di Negara Indonesia masih rendah.

Kualitas pendidikan dewasa ini menjadi salah satu topik yang paling banyak dibicarakan. Khususnya mata pelajaran matematika belum menunjukkan hasil maksimal sehingga perlu mendapat perhatian khusus, mengingat matematika merupakan cabang ilmu yang sangat penting dalam kehidupan seharihari. Karena peranannya yang begitu penting, maka konsep matematika harus dikuasai siswa sedini mungkin, terutama pada jenjang pendidikan dasar (SD, SMP dan SMA). Hal ini berguna untuk membekali mereka dengan kemampuan berpikir kritis, logis, sistematis, kreatif, dan kemampuan bekerja sama secara efektif. Kemampuan tersebut perlu dimiliki agar para siswa terlatih untuk mencari, mengolah, dan memanfaatkan informasi untuk digunakan dalam menghadapi permasalahan dalam kehidupan sehari-hari yang kian dinamis dan kompetitif.

Matematika adalah ilmu universal yang mendasari perkembangan ilmu pengetahuan dan teknologi modern, memajukan daya pikir serta analisis manusia. Matematika memiliki peranan besar dalam kehidupan. Beberapa ilmuwan menyatakan matematika adalah ratu sekaligus sebagai pelayan semua ilmu pengetahuan. Menyadari betapa pentingnya matematika, maka siswa dituntut agar dapat mempelajari matematika dengan sungguh-sungguh sehingga menghasilkan hasil belajar yang baik dan memuaskan.

Hasil belajar merupakan penilaian hasil dari proses pembelajaran. Penilaian hasil oleh setiap siswa dalam hal ini meliputi ranah kognitif, psikomotor, dan afektif yang di peroleh sebagai usaha kegiatan belajar dan dinilai dalam periode tertentu. Diantara ketiga ranah tersebut, ranah kognitif menjadi acuan utama penilaian yang paling banyak dilakukan oleh para guru di sekolah karena berkaitan dengan kemampuan para siswa dalam menguasai isi bahan pengajaran. Hasil belajar yang maksimal adalah salah satu tujuan siswa dalam mengikuti proses pembelajaran.

Hasil belajar matematika adalah perubahan perilaku siswa yang meliputi perubahan aspek kognitif, afektif, dan psikomotorik yang dicapai setelah melakukan pengalaman belajar. Pengalaman tersebut terkait dengan ilmu yang mempelajari tentang bentuk, susunan, besaran, konsep yang terhubung satu dengan lainnya. Hasil belajar matematika sampai hari ini masih dalam kajian dari peneliti baik itu dosen maupun mahasiswa. Banyak faktor yang mempengaruhi hasil belajar matematika siswa. Salah satu faktor yang mempengaruhi hasil belajar matematika siswa adalah faktor internal siswa. Oleh karena itu, perlu diteliti sampai berapa besar pengaruh faktor internal ini terhadap hasil belajar matematika siswa.

Berdasarkan hasil wawancara dengan guru bidang studi matematika siswa pada tanggal 28 februari 2018 nilai ulangan semester genap kelas VIII SMP Negeri 4 Kendari bahwa rata-rata hasil ulangan matematika semester genap tahun pelajaran 2017/2018 kelas VIII sangat rendah.Masih banyak siswa yang belum 
mencapai nilai Kriteria Ketuntasan Minimal (KKM). KKM yang ditetapkan sekolah tersebut untuk mata pelajaran matematika adalah 72 . Hasil belajar tersebut jelas terlihat dari hasil ulangan semester siswa yaitu sekitar $21,17 \%$ sudah mencapai standar kriteria ketuntasan minimal, tetapi masil ada pula $78,83 \%$ yang belum mencapai standar kriteria ketuntasan minimal. Hal ini menunjukkan bahwa terdapat masalah yang berkaitan dengan pelajaran matematika.

Menurut Gurganus dalam (Siregar, 2017: 224-225) pelajaran matematika merupakan pelajaran yang sampai saat ini masih dianggap sulit oleh para siswa. Siswa yang menganggap matematika sebagai pelajaran yang relatif sulit yang membentuk kesan dan pengalaman secara negatif terhadap matematika umumnya berdampak buruk bagi motivasi belajar siswa maupun penyesuaian akademik disekolah. Dari pengalaman negatif tersebut, banyak siswa yang berpersepsi bahwa matematika adalah pelajaran yang sangan menakutkan. Hal ini berdasarkan hasil wawancara dari beberapa siswa SMP Negeri 4 Kendari, masalah pertama adalah matematika merupakan pelajaran yang paling ditakuti siswa.mereka pun menganggap bahwa matematika adalah mata pelajaran yang menakutkan,mereka yang cenderung selalu bermalas-malasan,lebih memilih bergurau dengan temannya daripada memperhatikan penjelasan materi. Masalah kedua adalah setiap pelajaran matematika pasti ada satu atau dua orang siswa yang keluar masuk ruangan kelas saat jam pelajaran matematika berlangsung bahkan ada juga siswa yang membolos disaat jam pelajaran matematika berlangsung. Hal ini terlihat ketika peneliti mengikuti proses belajar mengajar matematika berlangsung. Masalah ketiga adalah saat guru memberikan soal latihan matematika ada saja siswa yang betanya jawaban pada temannya, bingung dan tidak tenang saat mengerjakan soal matematika, takut bertanya kepada guru padahal ada materi yang kurang jelas dan tidak dimengerti, siswa juga mudah gemetar dan berkeringat dingin ketika guru menunjuknya untuk mengerjakan soal di depan kelas. Hal ini menyebabkan hasil belajar matematika siswa menjadi rendah.

Rendahnya hasil belajar matematika siswa kelas VIII SMP Negeri 4 Kendari disebabkan beberapa faktor. Diantaranya adalah siswa masih belum memahami materi yang diajarkan oleh guru, masih terbiasa menghafal definisi, teorema, konsep, serta rumus-rumus matematika daripada pemahaman. Selain itu, faktor keluarga yaitu ketika siswa mendapatkan nilai matematika yang rendah siswa takut akan dimarahi orang tuanya dan dianggap bodoh. Hal ini memicu timbulnya kekhawatiran tersendiri bagi siswa yang akan belajar matematika. Faktor lainnya adalah guru yang masih menjadi sentral utama dalam proses pembelajaran, sebagian gurunya masih menggunakan metode ceramah dalam penyampaian materi sehingga siswa hanya duduk, mencatat, dan mendengarkan apa yang disampaikan. Hal ini membuat proses pembelajaran cenderung membosankan.

Selain faktor kecemasan matematika, ada faktor lain yang tidak kalah penting yang dapat mempengaruhi hasil belajar matematika siswa yaitu gaya belajar yang ada dalam diri seorang siswa.Banyak siswa yang tidak mengenali tipe gaya belajar yang ada pada dirinya sehingga kemungkinan menjadi faktor penghambat dalam menyerap materi yang diajarkan oleh guru. Jika siswa mengetahui gaya belajarnya maka ia dapat membantu dirinya sendiri dalam belajar lebih cepat dan lebih mudah juga tidak menutup kemungkinan menjadikan faktor keberhasilan dalam mencapai prestasi belajar.

Perlu disadari bahwa tidak semua siswa mempunyai gaya belajar yang sama. Meskipun siswa berada di sekolah atau bahkan duduk di kelas yang sama. Kemampuan siswa untuk memahami dan menyerap pelajaran sudah pasti berbeda. Ada yang cepat, sedang, dan ada pula yang sangat lambat. Karenanya, mereka seringkali menggunakan cara berbeda untuk memahami sebuah informasi atau pelajaran yang sama.

Masalah yang terjadi di lingkungan sekolah SMP Negeri 4 Kendari pada kelas VIII yaitu, siswa seringkali harus menempuh cara berbeda untuk bisa memahami sebuah informasi atau pelajaran. Sebagian siswa seringkali mencoret-coret ketika guru memberikan pelajaran, siswa lebih tertarik melihat keadaan di luar kelas daripada mendengarkan penjelasan dari guru. Ada juga siswa yang lebih suka mendengarkan ceramah daripada ia harus disuruh membaca buku. Terdapat juga siswa yang sering menggerakan anggota tubuh ketika berbicara karena dirasa dengan melakukan hal 
tersebut dia akan dapat berpikir atau belajar lebih cepat dan lebih baik daripada harus duduk dan diam. Pada proses pembelajaran di sekolah, gurupun tidak menerapkan kombinasi belajar sesuai dengan gaya belajar yang dimiliki siswanya sehingga cenderung hanya menggunakan satu metode pembelajaran yang tidak semua kalangan siswa dapat menyerap materi pembelajaran dengan baik. Hal inilah yang seharusnya menjadi perhatian guru matematika SMP Negeri 4 Kulisusu agar berusaha mengenali gaya belajar yang dimiliki siswanya agar mampu menerapkan metode belajar yang efektif. Sebagian siswa lebih suka guru mereka mengajar dengan cara menyampaikannya secara lisan dan mereka mendengarkan untuk bisa memahaminya. Sementara itu, ada siswa yang lebih suka membentuk kelompok kecil untuk mendiskusikan pertanyaan yang menyangkut pelajaran tersebut.

Deporter dan Hernacki (2013:112) mengelompokkan gaya belajar terbagi atas tiga macam yaitu gaya belajar visual, auditori dan kinestetik (V-A-K). Pelajar yang memiliki modalitas visual akan belajar melalui apa yang mereka lihat, pelajar auditorial belajar melalui apa yang mereka dengar, dan pelajar kinestetik belajar melakukannya melalui gerak dan sentuhan. Walaupun masing-masing dari individu belajar dengan menggunakan ketiga modalitas ini, pada tahapan tertentu kebanyakan orang lebih cenderung pada salah satu di antara ketiganya.

\section{Gaya Belajar Visual}

Menurut DePorter orang-orang bertipe visual memiliki ciri-ciri sebagai berikut (1) rapi dan teratur, (2) berbicara dengan cepat, (3) perencana dan mengatur jangka panjang yang baik, (4) teliti terhadap detail, (5) mementingkan penampilan, baik dalam hal pakaian maupun presentasi, (6) pengeja yang baik dan dapat melihat kata-kata yang sebenarnya dalam pikiran mereka, (7) mengingat apa yang dilihat dari pada apa yang didengar, (8) mengingat dengan asosiasi visual, (9) biasanya tidak terganggu oleh keributan, (10) mempunyai masalahuntuk mengingat instruksi verbal, kecuali jika ditulis, dan sering kali meminta bantuan orang untuk mengulanginya, (11) pembaca cepat dan tekun, (12) lebih suka membaca daripada dibacakan, membutuhkan pandangan dan tujuan yang menyeluruh dan bersikap waspada sebelum secara mental merasa pasti tentang suatu masalah atau proyek, (14) mencoret-coret tanpa arti selama berbicara di telepon dan dalam rapat, (15) lupa menyampaikan pesan verbal kepada orang lain, (16) sering menjawab pertanyaan dengan jawaban singkat ya atau tidak, (17) lebih suka melakukan demonstrasi daripada berpidato, (18) lebih suka seni daripada musik, (19) sering kali mengetahui apa yang harus dikatakan, tetapi tidak pandai memilih kata-kata, dan (20) kadang-kadang kehilangan konsentrasi ketika mereka ingin memperhatikan.

2. Gaya Belajar Auditorial

Menurut Deporter Orang-orang bertipe auditori memiliki ciri-ciri sebagai berikut:(1) berbicara kepada diri sendiri saat bekerja, (2) mudah terganggu oleh keributan, (3) menggerakan bibir mereka dan mengucapkan tulisan di buku ketika membaca, (4) senang membaca dengan keras dan mendengarkan, (5) dapat mengulangi kembali dan menirukan nada, birama, dan warna suara, (6) merasa kesulitan untuk menulis, tetapi hebat dalam bercerita, (7) berbicara dalam irama yang terpola, (8) biasanya pembicara yang fasih, (9) lebih suka musik daripada seni, (10) belajar dengan mendengarkan dan mengingat apa yang didiskusikan daripada yang dilihat, (11) suka berbicara, suka berdiskusi, dan menjelaskan sesuatu panjang lebar, (12) mempunyai masalah dengan pekerjaan-pekerjaan yang melibatkan visualisasi, seperti memotong bagian-bagian hingga sesuai satu sama lain, (13) lebih pandai mengeja dengan keras daripada menuliskannya dan (14) lebih suka gurauan lisan daripada membaca komik.

3. Gaya Belajar Kinestetik

Menurut Deporter orang-orang bertipe kinestetik memiliki ciri-ciri sebagai berikut (1) berbicara dengan perlahan, (2) menanggapi perhatian fisik, (3) menyentuh orang untuk mendapatkan perhatian mereka, (4) berdiri dekat ketika berbicara dengan orang, (5) selalu berorientasi pada fisik dan banyak gerak, (6) mempunyai perkembangan awal otot-otot yang besar, (7) belajar melalui memanipulasi dan praktik, (8) menghafal dengan cara berjalan dan melihat, (9) menggunakan jari sebagai penunjuk ketika membaca, (10) banyak menggunakan isyarat tubuh, (11) tidak dapat duduk diam untuk waktu lama, (12) tidak dapat mengingat geografi, kecuali jika mereka memang telah 
pernah berada di tempat itu, (13) menggunakan kata-kata yang mengandung aksi, (14) menyukai buku-buku yang berorientasi pada plot mereka mencerminkan aksi dengan gerakan tubuh saat membaca, (15) kemungkinan tulisannya jelek, (16) ingin melakukan segala sesuatu, dan (17) menyukai permainan yang menyibukkan.

Gaya belajar dianggap memiliki peranan penting dalam proses kegiatan belajar mengajar. Siswa yang kerap dipaksa belajar dengan cara-cara yang kurang cocok dan berkenan bagi mereka tidak menutup kemungkinan akan menghambat proses belajarnya terutama dalam hal berkonsentrasi saat menyerap informasi yang diberikan. Pada akhirnya hal tersebut juga akan berpengaruh pada hasil belajar yang belum maksimal sebagaimana yang diharapkan.

Berdasarkan pemaparan di atas penulis tertarik untuk melakukan penelitian yang berjudul "Pengaruh Kecemasan MatematikaTerhadap Hasil Belajar Matematika Ditinjau Dari Gaya Belajar Matematika SiswaKelas VIII SMP Negeri 4 Kendari”.

\section{Metode}

Jenis penelitian yang digunakan adalah ex post facto. Penelitian ex post facto merupakan susunan penelitian yang dilakukan untuk meneliti peristiwa yang telah terjadi dan kemudian melihat kebelakang untuk mengenai faktor-faktor yang dapat menimbulkan kejadian tersebut (Sujarweni, 2014:23).Populasi dalam penelitian ini adalah seluruh kelas VIII SMP Negeri 4 Kendari tahun ajaran 2018/2019 yang tersebar merata dalam 11 kelas paralel. Teknik Penarikan sampel pada setiap kelas dilakukan secara acak (Proportional Random sampling).

Variabel dalam penelitian ini terdiri dari variabel bebas yakni kecemasan matematika $(\mathrm{X})$, variabel antara yakni gaya belajar (Y), dan variabel terikat yakni hasil belajar matematika (Z). Untuk melihat gambaran hubungan antara ketiga variabel dalam penelitian ini, dapat dilihat dalam desain penelitian berikut:

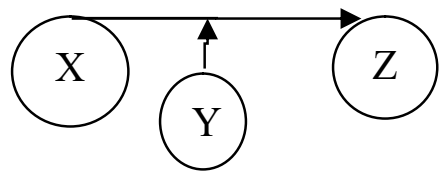

Gambar. Desain Penelitian
Keterangan :

$\mathrm{X}=$ Kecemasan Matematika

$\mathrm{Y}=$ Gaya Belajar

$\mathrm{Z}=$ Hasil Belajar Matematika

Instrumen yang digunakan dalam penelitian ini berbentuk angket. Angket yang yang dibuat terdiri dari butir-butir pernyataan, dimana untuk setiap pernyataan yang disajikan dalam angket tersebut disertai dengan empat alternatif jawaban. Jawaban telah disediakan sehingga responden hanya mengisi dengan menandai jawaban yang dipilihnya dengan tanda cek list atau centang dan untuk data mengenai hasil belajar matematika siswa $(Z)$ yaitu nilai tes hasil ulangan tengah semester siswa.

Sebelum digunakan, instrumen tersebut dianalisis terlebih dahulu melalui uji coba instrumen untuk mengetahui validitas dan reliabilitasnya.

\section{Hasil \\ Analisis Deskriptif}

Analisis deskriptif dimaksudkan untuk mengetahui gambaran tentang karakteristik responden (siswa) dari masing-masing variabel penelitian yaitu kecemasan matematika, gaya belajar (visual, auditorial, kinestetik) dan hasil belajar matematika siswa SMP Negeri 4 Kendari semester ganjil tahun ajaran 2018/2019.

Disitribusi pengelompokan kecemasan matematika siswa dalam pelajaran matematikaselengkapnya dapat dilihat pada tabel berikut ini:

Tabel 1.

Distribusi Kecemasan Matematika

\begin{tabular}{|c|c|c|c|}
\hline Nilai Interval & F & Persentase & Kategori \\
\hline $72 \leq X<96$ & 44 & $26,67 \%$ & Berat \\
\hline $48 \leq X<72$ & 64 & $38,79 \%$ & Sedang \\
\hline $24 \leq X<48$ & 57 & $34,54 \%$ & Ringan \\
\hline
\end{tabular}

Berdasarkan tabel 4.1 tersebut dapat dilihat bahwa siswa kelas VIII SMP Negeri 4 Kendari Terdiri atas $44(26,67 \%)$ siswa yang memiliki kecemasan pada pelajaran matematika dalam kategori berat. Adapun karakteristik dari siswa yang memiliki kecemasan dalam kategori ini yaitu dilihat dari fisik dengan ciri-ciri: keringat berlebih, tangan gemetar, dan jantung berdetak lebih cepat; kemudian dilihat dari segi kognitifnya dengan ciri-ciri: ketakutan, tidak 
berkonsentrasi, dan tidak punya rasa kepercayaan diri; dan dilihat dari segi afektifnya dengan ciri-ciri: munculnya sikap kurang senang, rasa gugup dan gelisah. Kemudian, 64 $(38,79 \%)$ siswa yang memiliki kecemasan pada pelajaran matematika dalam kategori sedang. Adapun karakteristik dari siswa yang memiliki kecemasan dalam kategori ini yaitu dilihat dari fisik dengan ciri - ciri: berkeringat dingin, tangan gemetar, dan jantung sedikit bergetar; kemudian dari segi kognitif meliputi: kepercayaan diri berkurang, takut gagal, dan hanya berfokus pada apa yang menjadi perhatiannya; dari segi fektif meliputi: sedikit kurang senang, gelisah, dan gugup. Kemudian, $57(34,54 \%)$ siswa yang memiliki kecemasan pada pelajaran matematika dalam kategori ringan. Adapun karakteristik dari siswa yang memiliki kecemasan dalam kategori ini yaitu dilihat dari segi fisik dengan ciri-ciri: gejala ringan berkeringat,tangan sedikit gemetar; kemudian dari segi kognitif dengan ciri-ciri: masih ada rasa kepercayaan diri, kemampuan diri, masih berkonsentrasi, tidak takut gagal, dan mampu menyelesaikan masalah aktual; dari segi afektif: gelisah atau tidak dapat duduk dengan tenang, kurang senang, suara kadang-kadang meninggi, dan sedikit gugup.

\section{Analisis Deskriptif Kecemasan Matematika Siswa Yang Bergaya Belajar Visual}

Disitribusi pengelompokan kecemasan matematika siswa yang bergaya belajar visual dalam pelajaran matematika selengkapnya dapat dilihat pada tabel berikut ini:

Tabel 2.

\section{Distribusi Kecemasan Matematika Siswa} yang Bergaya Belajar Visual

\begin{tabular}{|c|c|c|c|}
\hline $\begin{array}{c}\text { Nilai } \\
\text { Interval }\end{array}$ & $\mathbf{F}$ & Presentase & Kategori \\
\hline $72 \leq \mathrm{x}<96$ & 29 & $27,11 \%$ & Berat \\
\hline $48 \leq \mathrm{x}<72$ & 38 & $35,51 \%$ & Sedang \\
\hline $24 \leq \mathrm{x}<48$ & 40 & $37,38 \%$ & Ringan \\
\hline
\end{tabular}

Berdasarkan tabel tersebut dapat dilihat bahwa siswa kelas VIII SMP Negeri 4 Kendariyang bergaya belajar visual terdiri atas $29(27,11 \%)$ siswa yang memiliki kecemasan pada pelajaran matematika dalam kategori berat. Adapun karakteristik dari siswa yang memiliki kecemasan dalam kategori ini yaitu dilihat dari fisik dengan ciri-ciri: keringat berlebih, tangan gemetar, dan jantung berdetak lebih cepat; kemudian dilihat dari segi kognitifnya dengan ciri-ciri: ketakutan, tidak berkonsentrasi, dan tidak punya rasa kepercayaan diri; dan dilihat dari segi afektifnya dengan ciri-ciri:munculnya sikap kurang senang, rasa gugup dan gelisah. Kemudian,38(35\%) siswa yang memilikikecemasanpadapelajaranmatematikadal amkategorisedang.

Adapunkarakteristikdarisiswa yang memilikikecemasandalamkategoriiniyaitudilihat darifisikdenganciri-ciri: berkeringbergetar; kemudian dari segi kognitif meliputi: kepercayaan diri berkurang, takut gagal, dan hanya berfokus pada apa yang menjadi perhatiannya; dari segi fektif meliputi: sedikit kurang senang, gelisah, dan gugup. Kemudian, $40(37,38 \%)$ siswa yang memiliki kecemasan pada pelajaran matematika dalam kategori ringan. Adapun karakteristik dari siswa yang memiliki kecemasan dalam kategori ini yaitu dilihat dari segi fisik dengan ciri-ciri: gejala ringan berkeringat,tangan sedikit gemetar; kemudian dari segi kognitif dengan ciri-ciri: masih ada rasa kepercayaan diri, kemampuan diri, masih berkonsentrasi, tidak takut gagal, dan mampu menyelesaikan masalah aktual; dari segi afektif: gelisah atau tidak dapat duduk dengadingin, tangan gemetar, dan jantung sedikit $\mathrm{n}$ tenang, kurang senang, suara kadangkadang meninggi, dan sedikit gugup.

\section{Analisis Deskriptif Kecemasan Matematika Siswa Yang Bergaya Belajar Auditorial :}

Tabel 3.

Distribusi Kecemasan Matematika Siswa yang Bergaya Belajar Auditorial

\begin{tabular}{|l|l|l|l|}
\hline Interval & F & Presentase & Kategori \\
\hline $72 \leq \mathrm{x}<96$ & 5 & $21,73 \%$ & Berat \\
\hline $48 \leq \mathrm{x}<72$ & 12 & $52,17 \%$ & Sedang \\
\hline $24 \leq \mathrm{x}<48$ & 6 & $26,10 \%$ & Ringan \\
\hline
\end{tabular}

Berdasarkan tabel tersebut dapat dilihat bahwa siswa kelas VIII SMP Negeri 4 Kendari yang bergaya belajar auditorial terdiri atas 5 $(21,73 \%)$ siswa yang memiliki kecemasan pada pelajaran matematika dalam kategori berat. Adapun karakteristik dari siswa yang memiliki kecemasan dalam kategori ini yaitu dilihat dari fisik dengan ciri-ciri: keringat berlebih, tangan 
gemetar, dan jantung berdetak lebih cepat; kemudian dilihat dari segi kognitifnya dengan ciri-ciri: ketakutan, tidak berkonsentrasi, dan tidak punya rasa kepercayaan diri; dan dilihat dari segi afektifnya dengan ciri-ciri: munculnya sikap kurang senang, rasa gugup dan gelisah. Kemudian, $12(52,17 \%)$ siswa yang memiliki kecemasan pada pelajaran matematika dalam kategori sedang. Adapun karakteristik dari siswa yang memiliki kecemasan dalam kategori ini yaitu dilihat dari fisik dengan ciri-ciri: berkeringat dingin, tangan gemetar, dan jantung sedikit bergetar; kemudian dari segi kognitif meliputi: kepercayaan diri berkurang, takut gagal, dan hanya berfokus pada apa yang menjadi perhatiannya; dari segi fektif meliputi: sedikit kurang senang, gelisah, dan gugup. Kemudian, 6(26,10\%) siswa yang memiliki kecemasan pada pelajaran matematika dalam kategori ringan. Adapun karakteristik dari siswa yang memiliki kecemasan dalam kategori ini yaitu dilihat dari segi fisik dengan ciri-ciri: gejala ringan berkeringat,tangan sedikit gemetar; kemudian dari segi kognitif dengan ciri-ciri: masih ada rasa kepercayaan diri, kemampuan diri, masih berkonsentrasi, tidak takut gagal, dan mampu menyelesaikan masalah aktual; dari segi afektif: gelisah atau tidak dapat duduk dengan tenang, kurang senang, suara kadang-kadang meninggi, dan sedikit gugup.

\section{Analisis Deskriptif Kecemasan Matematika Siswa Yang Bergaya Belajar Kinestetik}

Disitribusi pengelompokan kecemasan matematika siswa yang bergaya belajar kinestetik dalam pelajaran matematika selengkapnya dapat dilihat pada tabel berikut ini:

Tabel 5.

Distribusi Kecemasan Matematika Siswa yang Bergaya Belajar Visual

\begin{tabular}{|c|c|c|c|}
\hline $\begin{array}{c}\text { Nilai } \\
\text { Interval }\end{array}$ & F & Presentase & Kategori \\
\hline $72 \leq \mathrm{x}<96$ & 9 & $25,71 \%$ & Berat \\
\hline $48 \leq \mathrm{x}<72$ & 14 & $40 \%$ & Sedang \\
\hline $24 \leq \mathrm{x}<48$ & 12 & $34,29 \%$ & Ringan \\
\hline
\end{tabular}

Berdasarkan tabel tersebut dapat dilihat bahwa siswa kelas VIII SMP Negeri 4 Kendari yang bergaya belajar kinestetik terdiri atas 9
(25,71\%) siswa yang memiliki kecemasan pada pelajaran matematika dalam kategori berat. Adapun karakteristik dari siswa yang memiliki kecemasan dalam kategori ini yaitu dilihat dari fisik dengan ciri-ciri: keringat berlebih, tangan gemetar, dan jantung berdetak lebih cepat; kemudian dilihat dari segi kognitifnya dengan ciri-ciri: ketakutan, tidak berkonsentrasi, dan tidak punya rasa kepercayaan diri; dan dilihat dari segi afektifnya dengan ciri-ciri: munculnya sikap kurang senang, rasa gugup dan gelisah. Kemudian, 14(40\%) siswa yang memiliki kecemasan pada pelajaran matematika dalam kategori sedang. Adapun karakteristik dari siswa yang memiliki kecemasan dalam kategori ini yaitu dilihat dari fisik dengan ciri - ciri: berkeringat dingin, tangan gemetar, dan jantung sedikit bergetar; kemudian dari segi kognitif meliputi: kepercayaan diri berkurang, takut gagal, dan hanya berfokus pada apa yang menjadi perhatiannya; dari segi fektif meliputi: sedikit kurang senang, gelisah, dan gugup. Dan $12(34,29 \%)$ siswa yang memiliki kecemasan pada pelajaran matematika dalam kategori ringan. Adapun karakteristik dari siswa yang memiliki kecemasan dalam kategori ini yaitu dilihat dari segi fisik dengan ciri-ciri: gejala ringan berkeringat,tangan sedikit gemetar; kemudian dari segi kognitif dengan ciri-ciri: masih ada rasa kepercayaan diri, kemampuan diri, masih berkonsentrasi, tidak takut gagal, dan mampu menyelesaikan masalah aktual; dari segi afektif: gelisah atau tidak dapat duduk dengan tenang, kurang senang, suara kadang-kadang meninggi, dan sedikit gugup.

Analisis Deskriptif Hasil Belajar Matematika

Distribusi nilai hasil belajar matematika siswa selengkapnya dapat dilihat pada tabel berikut ini.

Tabel 6.

Distribusi Hasil Belajar Matematika Siswa

\begin{tabular}{|c|c|c|c|}
\hline Interval & F & $\begin{array}{c}\text { Present } \\
\text { ase }\end{array}$ & Kategori \\
\hline $87 \leq \mathrm{y}<100$ & 8 & $4,85 \%$ & Baik sekali \\
\hline $70 \leq \mathrm{y}<85$ & 39 & $23,64 \%$ & Baik \\
\hline $55 \leq \mathrm{y}<70$ & 57 & $34,54 \%$ & Cukup \\
\hline $40 \leq \mathrm{y}<55$ & 41 & $24,85 \%$ & Kurang \\
\hline $\mathrm{Y}<40$ & 20 & $12,12 \%$ & $\begin{array}{c}\text { Kurang } \\
\text { Sekali }\end{array}$ \\
\hline
\end{tabular}

Berdasarkan tabel tersebut distribusi frekuensi hasil belajar matematika siswa kelas 
VIII SMP Negeri 4 Kendari menunjukan bahwa terdapat $8(4,85 \%)$ siswa yang memiliki hasil belajar matematika dalam kategori sangat baik, $39(23,64 \%)$ siswa yang memiliki hasil belajar matematika dalam kategori baik, 57 (34,54\%) siswa yang memiliki hasil belajar matematika dalam kategori cukup, $41(24,85 \%)$ siswa yang memiliki hasil belajar matematika dalam kategori kurang, dan $20(12,12 \%)$ siswa yang memiliki hasil belajar matematika dalam kategori sangat kurang.

\section{Hasil Analisis Inferensial}

Analisis yang digunakan dalam penelitian ini adalah uji hipotesis dengan uji-t. Melalui analisis inferensial, kita dapat mengetahui apakah hipotesis dalam penelitian ini data dimaksudkan untuk mengetahui apakah data berasal dari populasi yang berdistribusi normal atau tidak, sedangkan uji linearitas dimaksudkan untuk mengetahui apakah data yang diperoleh berhubungan linear atau tidak, jika datanya normal dan linear maka dilanjutkan dengan uji hipotesis. Berikut penjabaran dari tahap analisis inferensial.

\section{Uji Normalitas}

Uji normalitas data merupakan salah satu prasyarat untuk melakukan uji hipotesis yang dimaksudkan untuk mengetahui apakah data tersebut berdistribusi normal atau atau tidak. Uji Normalitas data setiap variabel pada penelitian ini menggunakan uji Kolmogorov-Smirnov dengan bantuan SPSS. Data hasil uji normalitas variabel kecemasan matematika (X), gaya belajar (Y) dan hasil belajar matematika siswa (Z) dapat dilihat pada tabel berikut ini:

Tabel 7. Hasil Uji Normalitas

\begin{tabular}{|l|c|c|c|}
\hline \multicolumn{4}{|c|}{ One-Sample Kolmogorov-Smirnov Test } \\
\hline & $\begin{array}{c}\text { Kecemasan } \\
\text { Matematika }\end{array}$ & $\begin{array}{c}\text { Gaya } \\
\text { Belajar }\end{array}$ & HBM \\
\hline $\begin{array}{c}\text { Sig } \\
\text { 2tailed }\end{array}$ & 0,06 & 0,06 & 0,16 \\
\hline
\end{tabular}

Berdasarkan tabel tersebut diperoleh nilai Kolmogorov-Smirnov $\mathrm{Z}$ untuk variabel kecemasan matematika, gaya belajar sebesar 0,06 dan hasil belajar matematika sebesar $0,16>$ signifikan $(\alpha)=0,05$ artinya data sampel variabel tersebut berasal dari populasi yang berdistribusi normal.

\section{Uji Linearitas}

Uji linearitas bertujuan untuk mengetahui apakah dua variabel mempunyai hubungan yang linear atau tidak secara signifikan pengujian pada SPSS dengan menggunakan Test For Linearity dengan taraf signifikan (Linearity) kurang dari 0,05. Tabel uji linearitas dengan mengunakan sofware SPSS sebagai berikut:

\section{Tabel 8.}

Uji Linearitas Variabel Kecemasan Matematika

\begin{tabular}{|c|c|c|}
\hline & $F$ & Sig. \\
\hline Linearity & 261,86 & 0,00 \\
\hline $\begin{array}{c}\text { Deviation from } \\
\text { Linearity }\end{array}$ & 1,09 & 0,35 \\
\hline
\end{tabular}

Dari output di atas dapat diketahui bahwa nilai signifikan pada linearity kecemasan matematika terhadap hasil belajar matematika $0,000<0,05$ dan nilai Deviation from Linerity kecemasan matematika terhadap hasil belajar matematika 0,350 >0,05 maka dapat dikatakan bahwa antara variabel kecemasan matematika dan hasil belajar matematika terhadap hubungan yang linear.

\section{Uji Hipotesis}

Pengujian hipotesis ini menggunakan rumus analisis regresi linear sederhana dengan bantuan IBMSPSS Statistics 21. Hipotesis yang akan di uji kebenarannya dalam penelitian ini adalah:

\section{a. Pengujian Hipotesis 1}

Hipotesis 1 yaitu untuk membuktikan pengaruh kecemasan matematika terhadap hasil belajar matematika siswa kelas VIII SMP Negeri 4 Kendari, maka digunakan analisis regresi sederhana. Adapun hipotesis statistiknya adalah:

$$
H_{0}: \beta_{1} \leq 0 \text { vs } H_{1}: \beta_{1}>0
$$

Hasil analisis regresi linear sederhana hipotesis 1 dapat dilihat pada tabel berikut: 


\begin{tabular}{|c|c|c|c|}
\hline & $\begin{array}{r}\text { Tabe } \\
\text { Coeeffic }\end{array}$ & & \\
\hline Model & & & \\
\hline & & $\mathrm{T}$ & Sig. \\
\hline (Constant) & B & & \\
\hline kecemasa & 102,81 & 36,12 & 0,00 \\
\hline $\begin{array}{c}\mathrm{n} \\
\text { matematik } \\
\mathrm{a}\end{array}$ & $-0,75$ & $-15,94$ & 0,00 \\
\hline
\end{tabular}

Berdasarkan tabel diatas, Coefficients diperoleh persamaan regresi pengaruh kecemasan matematika terhadap hasil belajar matematika yaitu:

$$
\hat{\mathrm{Y}}=102,81-0,75 \mathrm{X}
$$

Secara parsial pada variabel kecemasan matematika nilai $t_{\text {hitung }}=-15,94$. Selanjutnya, jika jika dibandingkan dengan $t_{\text {tabel }}$ dengan $\mathrm{df}=$ $\mathrm{n}-\mathrm{k}-1=165-1-1=163$ pada taraf kesalahan $5 \%$, maka $t_{\text {tabel }}=1,97$. Ternyata $t_{\text {hitung }}$ $<\mathrm{t}_{\text {tabel }(0,025 ; 163)}=1,97$ akan tetapi karena nilai signifikan nya $0,00<0,05$ maka $\mathrm{H}_{0}$ ditolak, ditolaknya $\mathrm{H}_{0}$ dapat disimpulkan bahwa variabel kecemasan matematika mempunyai pengaruh negatif yang signifikan terhadap hasil belajar matematika siswa.

\section{b. Pengujian Hipotesis 2}

Hipotesis 2 yaitu untuk membuktikan pengaruh kecemasan matematika siswa yang bergaya belajar visual terhadap hasil belajar matematika siswa kelas VIII SMP Negeri 4 Kendari, maka digunakan analisis regresi sederhana. Adapun hipotesis statistiknya adalah:

$$
H_{0}: \beta_{2} \leq 0 \text { vs } H_{1}: \beta_{2}>0
$$

Hasil analisis regresi linear sederhana hipotesis 2 dapat dilihat pada tabel berikut:

\section{Tabel 10.}

Coeefficients $^{\mathrm{a}}$

\begin{tabular}{|l|c|c|c|}
\hline \multicolumn{1}{|c|}{ Model } & & $\mathrm{T}$ & Sig. \\
\hline (Constant) & $\mathrm{B}$ & & \\
\cline { 2 - 4 } Kecemasan & 99.659 & 27.945 & 0.00 \\
\cline { 2 - 4 } $\begin{array}{l}\text { Matematik } \\
\text { a Siswa } \\
\text { yang }\end{array}$ & & & \\
Bergaya & -0.699 & -11.623 & 0.00 \\
Belajar & & & \\
Visual & & & \\
\hline
\end{tabular}

Berdasarkan tabel 4.14 Coefficients diperoleh persamaan regresi pengaruh kecemasan matematika terhadap hasil belajar matematika yaitu:

$$
\hat{\mathrm{Y}}=99,659-0,699 \mathrm{X}
$$

Secara parsial pada variabel kecemasan matematika nilai $t_{\text {hitung }}=-11,623$. Selanjutnya, jika jika dibandingkan dengan $t_{\text {tabel }}$ dengan $\mathrm{df}=$ $\mathrm{n}-\mathrm{k}-1=107-1-1=105$ pada taraf kesalahan $5 \%$, maka $t_{\text {tabel }}=1,98$. Ternyata $t_{\text {hitung }}$ $<\mathrm{t}_{\text {tabel }}(0,025 ; 105)=1,98$ akan tetapi karena nilai signifikan nya $0,00<0,05$ maka $\mathrm{H}_{0}$ ditolak, ditolaknya $\mathrm{H}_{0}$ dapat disimpulkan bahwa variabel kecemasan matematika siswa yang bergaya belajar visual mempunyai pengaruh negatif yang signifikan terhadap hasil belajar matematika siswa.

\section{c. Pengujian Hipotesis 3}

Hipotesis 3 yaitu untuk membuktikan pengaruh kecemasan matematika siswa yang bergaya belajar auditorial terhadap hasil belajar matematika siswa kelas VIII SMP Negeri 4 Kendari, maka digunakan analisis regresi sederhana. Adapun hipotesis statistiknya adalah:

$$
H_{0}: \beta_{3} \leq 0 \text { vs } H_{1}: \beta_{3}>0
$$

Hasil analisis regresi linear sederhana hipotesis 3 dapat dilihat pada tabel berikut:

Tabel 11.

\section{Coeeffisients}

\begin{tabular}{|l|c|c|c|}
\hline \multicolumn{1}{|c|}{ Model } & & $\mathrm{T}$ & Sig. \\
\hline (Constant) & $\mathrm{B}$ & & \\
\cline { 2 - 4 } Kecemasan & 108.459 & 12.115 & 0.00 \\
\cline { 2 - 4 } Matematika & & & \\
Siswa yang & & & \\
Bergaya & -0.883 & -6.212 & 0.00 \\
$\begin{array}{l}\text { Belajar } \\
\text { Auditorial }\end{array}$ & & & \\
\hline
\end{tabular}

Berdasarkan tabelCoefficients diatasdiperoleh persamaan regresi pengaruh kecemasan matematika siswa yang bergaya belajar auditorial terhadap hasil belajar matematika yaitu:

$$
\hat{Y}=108,459-0,883 \mathrm{X}
$$

Secara parsial pada variabel kecemasan matematika nilai $t_{\text {hitung }}=-6,212$. Selanjutnya, jika jika dibandingkan dengan $t_{\text {tabel }}$ dengan $\mathrm{df}=$ $\mathrm{n}-\mathrm{k}-1=23-1-1=21$ pada taraf kesalahan $5 \%$, maka $t_{\text {tabel }}=2,08$. Ternyata $t_{\text {hitung }}<t_{\text {tabel }}(0,025$; $21)=2,08$ akan tetapi karena nilai signifikan nya $0,00<0,05$ maka $\mathrm{H}_{0}$ ditolak, ditolaknya $\mathrm{H}_{0}$ dapat disimpulkan bahwa variabel kecemasan matematika siswa yang bergaya belajar 
auditorial mempunyai pengaruh negatif yang signifikan terhadap hasil belajar matematika siswa.

Kemudian untuk mengetahui hubungan antara variabel tersebut dapat dilihat pada tabel koefisien korelasi berikut:

\section{d. Pengujian Hipotesis 4}

Hipotesis 4 yaitu untuk membuktikan pengaruh kecemasan matematika siswa yang bergaya belajar kinestetik terhadap hasil belajar matematika siswa kelas VIII SMP Negeri 4 Kendari, maka digunakan analisis regresi sederhana. Adapun hipotesis statistiknya adalah:

$$
H_{0}: \beta_{4} \leq 0 \text { vs } H_{1}: \beta_{4}>0
$$

Hasil analisis regresi linear sederhana hipotesis 4 dapat dilihat pada tabel berikut:

Tabel 12.

Coeeficcients

\begin{tabular}{|l|c|c|c|}
\hline \multicolumn{1}{|c|}{ Model } & $\begin{array}{c}\text { Unstandadize } \\
\mathrm{d} \\
\text { Coefficients }\end{array}$ & $\mathrm{T}$ & Sig. \\
\hline (Constant) & $\mathrm{B}$ & & \\
\cline { 2 - 4 } $\begin{array}{l}\text { Kecemasan } \\
\text { Matematik } \\
\text { a Siswa } \\
\text { yang }\end{array}$ & 109.258 & 21.241 & 0.00 \\
$\begin{array}{l}\text { Bergaya } \\
\text { Belajar } \\
\text { Kinestetik }\end{array}$ & -0.834 & -9.929 & 0.00 \\
\hline
\end{tabular}

Berdasarkan tabel Coefficients diatasdiperoleh persamaan regresi pengaruh kecemasan matematika siswa yang bergaya belajar kinestetik terhadap hasil belajar matematika yaitu:

$$
\hat{Y}=109,258-0,834 X
$$

Secara parsial pada variabel kecemasan matematika nilai $t_{\text {hitung }}=-6,212$. Selanjutnya, jika jika dibandingkan dengan $t_{\text {tabel }}$ dengan $\mathrm{df}=$ $\mathrm{n}-\mathrm{k}-1=35-1-1=33$ pada taraf kesalahan $5 \%$, maka $t_{\text {tabel }}=2,03$. Ternyata $t_{\text {hitung }}<t_{\text {tabel }}(0,025 ;$ 33) $=2,03$ akan tetapi karena nilai signifikan nya $0,00<0,05$ maka $\mathrm{H}_{0}$ ditolak, ditolaknya $\mathrm{H}_{0}$ dapat disimpulkan bahwa variabel kecemasan matematika siswa yang bergaya belajar kinestetik mempunyai pengaruh negatif yang signifikan terhadap hasil belajar matematika siswa.

\section{Pembahasan}

Salah satu faktor pemicu yanng menyebabkan rendahnya hasil belajar matematika siswa di sekolah yaitu sebagian besar siswa masih menganggap matematika adalah mata pelajaran yang sangat menakutkan. Rasa takut yang timbul tersebut dapat menimbulkan kecemasan siswa saat sedang belajar matematika. kecemasan terhadap matematika tidak bisa dipandang sebagai hal biasa saja, karena hal ini terjadi karena ketidakmampuan siswa dalam beradaptasi pada pelajaran matematika yang menyebakan hasil belajar matematika siswa semakin rendah.

Penelitian ini diadakan di SMP Negeri 4 Kendari. Tujuan dari penelitian ini adalah untuk mengetahui deskripsi kecemasan matematika, gaya belajar, dan hasil belajar matematika siswa, dan untuk mengetahui pengaruh yang sisgnifikan antara kecemasan matematika terhadap hasil belajar matematika ditinjau dari gaya belajar (visual, auditorial, dan kinestetik). Penelitian ini diambil sampel sebanyak 165 siswa kelas VIII yang tersebar merata dalam 11 kelas paralel. Berdasarkan hasil analisis deskriptif yang dilakukan untuk variabel kecemasan matematika diperoleh 44 (26,67\%) siswa yang memiliki kecemasan matematika dalam kategori berat, sebanyak 64 (38,79\%) siswa yang memiliki kecemasan matematika dalam kategori sedang, dan sebanyak 57 $(34,54 \%)$ siswa yang memiliki kecemasan matematika dalam kategori ringan. Sedangkan hasil analisis deskriptif yang untuk gaya belajar diperoleh 107 (64,85\%) siswa yang memiliki gaya belajar visual, sebanyak $23(13,94 \%)$ siswa yang memiliki gaya belajar auditorial, dan sebanyak $35(21,21 \%)$ siswa yang memiliki gaya belajar kinestetik. Pada variabel hasil belajar matematika siswa kelas VIII SMP Negeri 4 Kendari, nilai rata- rata yang dihasilkan secara keseluruhan adalah 59,13 dengan median 61, standar deviasi sebesar 15,77, dan modus sebesar 61 .

Pengaruhkecemasan matematika terhadap hasil belajar matematika ditinjau dari gaya belajar siswa kelas VIII SMP Negeri 4 Kendari ini diperoleh dengan melakukan uji hipotesis dengan menggunakan uji statistik regresi linear sederhana. Namun sebelum dilakukan uji hipotesis, terlebih dahulu dilakukan uji prasyarat analisis yaitu uji normalitas yang bertujuan untuk melihat sebaran 
data variabel apakah berdistribusi normal atau tidak, dan uji linearitas yang bertujuan untuk mengetahui apakah data variabel tersebut memiliki hubungan yang linear atau tidak..

Hasil uji normalitas data menggunakan uji kolmogorov-smirnov, data kecemasan matemmatika, gaya belajar, dan hasil belajar matematika siswa kelas VIII SMP Negeri 4 kendari berdistribusi normal. Berdasarkan tabel 4.10 dan 4.11 hasil uji linearitas diketahui bahwa nilai signifikan pada linearity kecemasan matematika adalah $0,000<0,05$ maka dapat dikatakan bahwa variabel kecemasan matematika terhadap hasil belajar matematika mempunyai hubungan yang linear.

Berdasarkan hasil pengujian hipotesis 1 dipeoleh bahwa kecemasan matematika berpengaruh negatif terhadap hasil belajar matematika siswa kelas VIII SMP Negeri 4 Kendari. Hal ini dapat diketahui dari nilai $\mathrm{t}_{\text {hitung }}$ $=-15,94<\mathrm{t}_{\text {tabel }}=1,97$ dan nilai signifikannya $0,000<0,05$. Artinya, kecemasan matematika mempunyai pengaruh negatif terhadap hasil belajar matematika siswa. Hal ini sesuai dengan penelitian yang dilakukan Ekawati (2015) yang menyimpulkan bahwa terdapat pengaruh yang signifikan antara kecemasan terhadap hasil belajar matematika siswa kelas VII SMP Negeri 13 Banjarmasin.

Selanjutnya, dari hasil analisis regresi sederhana dipeoleh persamaan regresi yaitu $\hat{Y}=$ $102,81-0,75 \mathrm{X}_{1}$. Persamaan tersebut menunjukkan koefisien $x_{1}$ sebesar $-0,75$. Hal ini berarti apabila variabel kecemasan matematika dinaikkan satu-satuan maka hasil belajar matematika akan menurun sebesar 0,75 . Terlihat juga bahwa nilai konstan dari persamaan tersebut positif, hal ini dikarenakan pengaruh yang diberikan oleh kecemasan matematika terhadap hasil belajar matematika tergolong kuat dan rentang nilai yang diperoleh siswa antara kecemasan matematika dan hasil belajar matematika sangat jauh.

Kemudian dari hasil analisis regresi sederhana juga ini didapatkan besarnya koefisien korelasi yakni 0,78. Makna dari hasil analisis regresi dan besarnya koefisien korelasi tersebut yakni menunjukkan semakin tinggi kecemasan matematika siswa, maka akan semakin rendah hasil belajar matematikanya. Berarti terdapat pengaruh yang negatif dan signifikan kecemasan matematika terhadap hasil belajar matematika siswa kelas VIII SMP
Negeri 4 Kendari. Oleh karena itu, dapat dikatakan bahwa semakin tinggi kecemasan matematika yang dimiliki oleh seorang siswa akan memberikan pengaruh yang negatif dan signifikan terhadap penurunan hasil belajar matematikanya.

Besarnya kontribusi kecemasan matematika terhadap hasil belajar matematika siswa kelas VIII SMP Negeri 4 Kendari dapat dilihat dari koefisien determinasi (R-Square) yaitu 0,61. Artinya, variabel kecemasan matematika memberikan kontribusi terhadap hasil belajar matematika sebesar $61 \%$ dan sisanya 39\% dipengaruhi oleh variabel lain yang tidak dibahas pada penelitian ini. Dari hasil penelitian ini, kontribusi yang diberikan kecemasan matematika terhadap hasil belajar matematika tergolong besar, hal ini disebabkan karena rasa ketakuatan yang dimiliki seorang siswa dapat menimbulkan kecemasan yang berlebihan saat siswa tersebut sedang belajar atau saat akan berinteraksi dengan matematika.

Berdasarkan hasil pengujian hipotesis 2 diperoleh bahwa kecemasan matematika siswa yang bergaya belajar visual berpengaruh negatif terhadap hasil belajar matematika siswa kelas VIII SMP Negeri 4 Kendari. Hal ini dapat diketahui dari nilai $t_{\text {hitung }}=-11,623<\mathrm{t}_{\text {tabel }}=1,98$ dan nilai signifikannya $0,00<0,05$. Artinya, kecemasan matematika siswa yang bergaya belajar visual mempunyai pengaruh negatif terhadap hasil belajar matematika siswa. Selanjutnya, dari hasil analisis regresi sederhana diperoleh persamaan regresi yaitu $\hat{Y}=99,659$ 0,699X. Persamaan tersebut menunjukkan koefisien X sebesar $-0,699$. Hal ini berarti apabila variabel kecamasan matematika jika dinaikkan 1 satuan maka hasil belajar matematika akan mengalami penurunan sebesar 0,699 . Terlihat juga bahwa nilai konstan dari persamaan tersebut positif. Hal ini dikarenakan pengaruh yang diberikan oleh kecemasan matematika siswa yang bergaya belajar visual terhadap hasil belajar matematika tergolong kuat dan rentang nilai yang diperoleh siswa antara kecemasan matematika siswa yang bergaya belajar visual dan hasil belajar matematika sangat jauh.

Kemudian dari hasil analisis regresi sederhana juga ini didapatkan besarnya koefisien korelasi yakni 0,75 . Makna dari hasil analisis regresi dan besarnya koefisien korelasi tersebut yakni menunjukkan semakin tinggi 
kecemasan matematika siswa, maka akan semakin rendah pula hasil belajar matematikanya. Berarti terdapat pengaruh yang negatif dan signifikan kecemasan matematika siswa yang bergaya belajar visual terhadap hasil belajar matematika siswa kelas VIII SMP Negeri 4 Kendari.

Besarnya kontribusi kecemasan matematika siswa yang bergaya belajar visual terhadap hasil belajar matematika siswa kelas VIII SMP Negeri 4 Kendari dapat dilihat dari koefisien determinasi ( $R$ Square) yaitu 0,563. Artinya, variabel kecemasan matematika memberikan kontribusi terhadap hasil belajar matematika siswa yang bergaya belajar visual sebesar $\quad 56,3 \%$ dan sisanya $43,7 \% \%$ dipengaruhi oleh variabel lain yang tidak dibahas pada penelitian ini. Dari hasil penelitian ini, kontribusi yang diberikan kecemasan matematika siswa yang bergaya belajar visual terhadap hasil belajar matematika tergolong besar.

Berdasarkan hasil pengujian hipotesis 3 diperoleh bahwa kecemasan matematika siswa yang bergaya belajar auditorial berpengaruh negatif terhadap hasil belajar matematika siswa kelas VIII SMP Negeri 4 Kendari. Hal ini dapat diketahui dari nilai $t_{\text {hitung }}=-6,212<\mathrm{t}_{\text {tabel }}=2,08$ dan nilai signifikannya $0,00<0,05$. Artinya, kecemasan matematika siswa yang bergaya belajar auditorial mempunyai pengaruh negatif terhadap hasil belajar matematika siswa. Selanjutnya, dari hasil analisis regresi sederhana diperoleh persamaan regresi yaitu $\hat{Y}=108,459$ 0,883X. Persamaan tersebut menunjukkan koefisien X sebesar $-0,883$. Hal ini berarti apabila variabel kecamasan matematika jika dinaikkan 1 satuan maka hasil belajar matematika akan mengalami penurunan sebesar 0,883 . Terlihat juga bahwa nilai konstan dari persamaan tersebut positif. Hal ini dikarenakan pengaruh yang diberikan oleh kecemasan matematika siswa yang bergaya belajar auditorial terhadap hasil belajar matematika tergolong kuat dan rentang nilai yang diperoleh siswa antara kecemasan matematika siswa yang bergaya belajar auditorial dan hasil belajar matematika sangat jauh.

Kemudian dari hasil analisis regresi sederhana juga ini didapatkan besarnya koefisien korelasi yakni 0,805 . Makna dari hasil analisis regresi dan besarnya koefisien korelasi tersebut yakni menunjukkan semakin tinggi kecemasan matematika siswa, maka akan semakin rendah pula hasil belajar matematikanya. Berarti terdapat pengaruh yang negatif dan signifikan kecemasan matematika siswa yang bergaya belajar auditorial terhadap hasil belajar matematika siswa kelas VIII SMP Negeri 4 Kendari.

Besarnya kontribusi kecemasan matematika siswa yang bergaya belajar auditorial terhadap hasil belajar matematika siswa kelas VIII SMP Negeri 4 Kendari dapat dilihat dari koefisien determinasi ( $R$ Square) yaitu 0,648. Artinya, variabel kecemasan matematika memberikan kontribusi terhadap hasil belajar matematika siswa yang bergaya belajar auditorial sebesar $64,8 \%$ dan sisanya $43,7 \%$ dipengaruhi oleh variabel lain yang tidak dibahas pada penelitian ini. Dari hasil penelitian ini, kontribusi yang diberikan kecemasan matematika siswa yang bergaya belajara uditorial terhadap hasil belajar matematika tergolong besar.

Berdasarkan hasil pengujian hipotesis 4 diperoleh bahwa kecemasan matematika siswa yang bergaya belajar kinestetik berpengaruh negatif terhadap hasil belajar matematika siswa kelas VIII SMP Negeri 4 Kendari. Hal ini dapat diketahui dari nilai $t_{\text {hitung }}=-9,929<\mathrm{t}_{\text {tabel }}=2,03$ dan nilai signifikannya $0,00<0,05$. Artinya, kecemasan matematika siswa yang bergaya belajar kinestetik mempunyai pengaruh negatif terhadap hasil belajar matematika siswa. Selanjutnya, dari hasil analisis regresi sederhana diperoleh persamaan regresi yaitu $\hat{Y}=109,258$ $0,834 X$. Persamaan tersebut menunjukkan koefisien $\mathrm{X}$ sebesar $-0,834$. Hal ini berarti apabila variabel kecamasan matematika jika dinaikkan 1 satuan maka hasil belajar matematika akan mengalami penurunan sebesar 0,834 . Terlihat juga bahwa nilai konstan dari persamaan tersebut positif. Hal ini dikarenakan pengaruh yang diberikan oleh kecemasan matematika siswa yang bergaya belajar kinestetik terhadap hasil belajar matematika tergolong kuat dan rentang nilai yang diperoleh siswa antara kecemasan matematika siswa yang bergaya belajar kinestetik dan hasil belajar matematika sangat jauh.

Kemudian dari hasil analisis regresi sederhana juga ini didapatkan besarnya koefisien korelasi yakni 0,866. Makna dari hasil analisis regresi dan besarnya koefisien korelasi tersebut yakni menunjukkan semakin tinggi 
kecemasan matematika siswa, maka akan semakin rendah pula hasil belajar matematikanya. Berarti terdapat pengaruh yang negatif dan signifikan kecemasan matematika siswa yang bergaya belajar kinestetik terhadap hasil belajar matematika siswa kelas VIII SMP Negeri 4 Kendari.

Besarnya kontribusi kecemasan matematika siswa yang bergaya belajar kinestetik terhadap hasil belajar matematika siswa kelas VIII SMP Negeri 4 Kendari dapat dilihat dari koefisien determinasi ( $R$ Square) yaitu 0,749 . Artinya, variabel kecemasan matematika memberikan kontribusi terhadap hasil belajar matematika siswa yang bergaya belajar kinestetik sebesar $74,9 \%$ dan sisanya $25,1 \%$ dipengaruhi oleh variabel lain yang tidak dibahas pada penelitian ini. Dari hasil penelitian ini, kontribusi yang diberikan kecemasan matematika siswa yang bergaya belajar kinestetik terhadap hasil belajar matematika tergolong besar.

\section{Simpulan dan Saran}

\section{Simpulan}

Berdasarkan hasil analisis dan pembahasan yang diperoleh maka dapat disimpulkan sebagai berikut:

1. Kecemasan matematika siswa kelas VIII SMP Negeri 4 Kendari mempunyai nilai 24 sebagai nilai terendah, 88 sebagai nilai tertinggi dan nilai rata-rata 58,02. Sementara untuk gaya belajar siswa kelas VIII SMP Negeri 4 Kendari mempunyai nilai 53 sebagai nilai terendah, 98 sebagai nilai tertinggi dan nilai rata-rata 78,33. dan hasil belajar matematika siswa kelas VIII SMP Negeri 4 Kendari mempunyai ratarata nilai sebesar 59,13. dengan 27 sebagai nilai terendah dan 92 sebagai nilai tertinggi.

2. Kecemasan matematika siswa mempunyai pengaruh yang negatif dan signifikan terhadap hasil belajar matematika siswa kelas VIII SMP Negeri 4 Kendari Tahun Ajaran 2018/2019 pada semester ganjil. Hal tersebut dapat dilihat pada nilai $\mathrm{t}_{\text {hitung }}=$ $15,623<\mathrm{t}_{\text {tabel }}(0,025 ; 105)=1,97$ dan nilai sig. $0,000<\alpha=0,05$ yang berarti bahwa kecemasan matematika berpengaruh negatif terhadap hasil belajar matematika siswa. Hal tersebut dapat pula dilihat dari hasil persamaan regresinya yaitu $\hat{Y}=102,81$ -
0,75X dengan pengaruh terhadap hasil belajar matematika sebesar $61 \%$ dan sisanya $39 \%$ dipengaruhi oleh faktor lain.

3. Kecemasan matematika siswa yang bergaya belajar visual mempunyai pengaruh yang negatif dan signifikan terhadap hasil belajar matematika siswa kelas VIII SMP Negeri 4 Kendari Tahun Ajaran 2018/2019 pada semester ganjil. Hal tersebut dapat dilihat pada nilai $\mathrm{t}_{\text {hitung }}=-11,623<\mathrm{t}_{\text {tabel }}(0,025 ; 105)=$ 1,98 dan nilai sig. $0,000<\alpha=0,05$ yang berarti bahwa kecemasan matematika siswa yang bergaya belajar visual berpengaruh negatif terhadap hasil belajar matematika siswa. Hal tersebut dapat pula dilihat dari hasil persamaan regresinya yaitu $\hat{Y}$ $=99,659-0,699 \mathrm{X}$ ) dengan pengaruh terhadap hasil belajar matematika sebesar $56 \%$ dan sisanya $44 \%$ dipengaruhi oleh faktor lain.

4. Kecemasan matematika siswa yang bergaya belajar auditorial mempunyai pengaruh yang negatif dan signifikan terhadap hasil belajar matematika siswa kelas VIII SMP Negeri 4 Kendari Tahun Ajaran 2018/2019 pada semester ganjil. Hal tersebut dapat dilihat pada nilai $\mathrm{t}_{\text {hitung }}=-6,212<\mathrm{t}_{\text {tabel }}(0,025$; ${ }_{21)}=2,08$ dan nilai sig. $0,000<\alpha=0,05$ yang berarti bahwa kecemasan matematika berpengaruh negatif terhadap hasil belajar matematika siswa. Hal tersebut dapat pula dilihat dari hasil persamaan regresinya yaitu $\hat{Y}=108,81-0,883 \mathrm{X})$ dengan pengaruh terhadap hasil belajar matematika sebesar $64,8 \%$ dan sisanya $35,2 \%$ dipengaruhi oleh faktor lain.

5. Kecemasan matematika siswa yang bergaya belajar kinestetik mempunyai pengaruh yang negatif dan signifikan terhadap hasil belajar matematika siswa kelas VIII SMP Negeri 4 Kendari Tahun Ajaran 2018/2019 pada semester ganjil. Hal tersebut dapat dilihat pada nilai $\mathrm{t}_{\text {hitung }}=-9,929<\mathrm{t}_{\text {tabel }}(0,025$; ${ }_{33)}=2,03$ dan nilai sig. $0,000<\alpha=0,05$ yang berarti bahwa kecemasan matematika berpengaruh negatif terhadap hasil belajar matematika siswa. Hal tersebut dapat pula dilihat dari hasil persamaan regresinya yaitu $\hat{\mathrm{Y}}=109,258-0,883 \mathrm{X}$ dengan pengaruh terhadap hasil belajar matematika sebesar $74,9 \%$ dan sisanya $25,1 \%$ dipengaruhi oleh faktor lain. 


\section{Saran}

Berdasarkan pembahasan dan kesimpulan di atas, maka peneliti menyarankan beberapa hal sebagai berikut:

1. Bagi guru, melihat ada pengaruh kuat antara kecemasan matematika terhadap hasil belajar matematika maka disarankan kepada guru agar dapat membantu meminimalkan kecemasan matematika siswa tersebut melalui proses pembelajaran yang menyenangkan dan nyaman bagi siswa, menanamkan rasa percaya diri terhadap siswa dalam menyelesaikan soal matematika. Dan bagi guru, melihat ada pengaruh kuat antara gaya belajar terhadap hasil belajar matematika maka disarankan kepada guru agar dapat mengajak siswanya agar mengenali tipe gaya belajar yang ada pada masing-masing siswa dan menyadarkan siswanya akan pentingnya jika mengoptimalkan gaya belajar dengan baik. Guru juga harus menyesuaikan cara mengajarnya dengan tipe gaya belajar yang dimiliki siswa serta tidak monoton pada satu metode mengajar.

2. Bagi peneliti selanjutnya, setelah mengetahui lebih dalam tentang kecemasan matematika dan gaya belajar diharapkan dapat memberikan solusi yang baik tentang bagaimana siswa akan meminimalisir rasa kecemasan yang dimilikinya sehingga siswa tersebut akan terus belajar agar dapat memacu hasil belajarnya dengan baik dan selalu mengaitkan kemampuan gaya belajar siswa dengan materi yang terkai pada mata pelajaran matematika.

\section{Daftar Pustaka}

Anggraeni. 2010.Hubungan Antara Kecemasan Dalam Menghadapi Mata Pelajaran Matematika Dengan Prestasi Akademik Matematika Pada Remaja. Skripsi. Program Sarjana Psikologi Universitas Gunadarma. Depok.
Anita. 2014. Pengaruh kecemasan Matematika (Mathematic Anxiety) Terhadap kemampuan koneksi Matematis Siswa SMP. Jurnal ilmiah Program Studi Matematika STKIP Siliwangi Bandung. Vol 3. No 1,2014, hal:125-132.

Aprilia.2017.Pengaruh Kecemasan Belajar terhadap Hasil Belajar Matematika Siswa Kelas X SMA Negeri 1 G.Skripsi. Program Sarjana Pendidikan Matematika Universitas Halu Oleo. Kendari.

Aunurrahman.2012. Belajardan Pembelajaran. Bandung:Alfa Beta.

Deporter, Bobbi and Mike, Hernacki. 2013. Quantum Learning. Bandung: Kalfa PT Mizan Pustaka.

Ekawati, A. 2015. Pengaruh Kecemasan Terhadap Hasil Belajar Matematika SiswaKelas VII SMPN 13 Banjarmasin. Jurnal Pendidikan Matematika STKIP PGRI Banjarmasin. Vol 1. No 3, 2015, hal: 164-169.

Faradiba. 2016. Pseudo Kecemasan Matematika.Jurnal Pendidikan Matematika FKIP Universitas Islam Malang. Vol 2. No 2, 2016, hal : 166-171.

Freedman, Ellen. 2012. Do You Have Math Anxiety ? Aself Test.(Online): (www.mathpower.com/anxtest.ht $\underline{\mathrm{ml}}$, diakses pada tanggal 23 Desember 2013).

Ghufron, Nur dkk. 2012. Gaya Belajar Kajian Teoritik. Yogyakarta: Pustaka Pelajar.

Hawari, D. 2001. Manajemen Stres Cemas dan Depresi. Jakarta: Balai Penerbit FKUI. 